\title{
GENOMIC PROFILING OF F 1 HYBRIDS OF DURIAN (DURIO ZIBETHINUS) REVEALED BY RAPD-PCR
}

\author{
Riry PRIHATINI*, Farihul IHSAN, Ni Luh Putu INDRIYANI \\ ${ }^{1}$ Indonesian Tropical Fruit Research Institute, \\ Jalan Raya Solok-Aripan Km. 8 Solok 27301, Sumatra Barat, Indonesia
}

Received: March 2015; Accepted: November 2016

\begin{abstract}
The molecular analysis of 32 durian $F_{1}$ hybrids, resulted from crossing of the Arp 8990 (female parent) and 'Otong' (male parent), was conducted in order to determine the genetic characteristics of hybrids and parents, as it would be followed/evidenced by the variability of traits produced from the cross breeding. The RAPD analyses of 14 primers resulted in 114 scoring bands, 112 (98.2\%) of them were polymorphic, with 4 to 11 bands amplified per primer. The electrophoresis gel of the PCR results revealed that some hybrids produced different band patterns compared to the parents; this indicated the crossing between parents' alleles and trait combinations from both the parents. The Dice-Sorensen similarity coefficient demonstrated that most of the hybrids had distant genetic similarities with both parents, which were ranged from $0.141[71 \mathrm{~B}(4)$ and $72 \mathrm{~B}(15)]$ to $0.776[71 \mathrm{~B}(15)$ and $48 \mathrm{~B}(1)]$. The UPGMA method was used to construct the dendrogram, which grouped the hybrids in five clusters with distinct genetic relationships and was confirmed with the PCA analysis. This result implied that above crossing produced hybrids having characters different from the parents.
\end{abstract}

Key words: cross breeding, Durio zibethinus, hybrids, RAPD

\section{INTRODUCTION}

Durian (Durio zibethinus Murr.) is a fruit crop originating from Borneo, Indonesia (Nanthachai 1994; Brown 1997). Over 30 species of Durio have been described that can be found in Borneo, Malaya, and Sumatra (Brown 1997). Since durian is an open pollinating plant, there many varieties are hybrids available as material for selections. However, such hybrids usually have low productivity and cultivars derived from them have limited desired characters. In order to improve the natural durian crossbreed, the interspecific and intraspecific cross breeding can be chosen as an alternative. Indonesian Tropical Fruit Research Institute (ITFRI) has conducted durian cross breeding since 2010, and it has collected hybrids of more than 15 cross combinations.

The variability of plants produced from crossings can be determined using both morphological and genetic characteristics. Morphological characters are usually based on the phenotypic expression, namely, fruit and thorns shape, taste, flower and foliage color, or other traits (Janyszek et al. 2008; Rivero-Guerra 2011). However, due to the plant's plasticity, the morphological characters have a limited capacity to distinguish individuals that are genetically similar (Klingenberg et al. 2011; Gratani 2014). In order to complete the morphological characters, molecular markers are used as a standard method for studying the genetic diversity (Withlock et al. 2010; Gerrano et al. 2014).

RAPD (Random Amplified Polymorphic DNA) method has been used extensively to estimate the genetic diversity based on the unique sequences of nucleotides in the plant genome (Bardakci 2001). This technique does not require initial information about the tested genome, although the number of characters observed is virtually unlimited, 
the method is fast, easy to execute, and requires only small amounts of DNA (0.5 ng) as a template (Williams et al. 1990; Welsh \& McClelland 1990).

The study was conducted in order to determine the genomic characteristics of the hybrids and parents, reflecting the variability of traits resulting from cross breeding.

\section{MATERIALS AND METHODS}

\section{Durian cross breeding}

The female flowers of Arp 8990 were prepared by cutting the flower's petals and covering it with paper bag to avoid uncontrolled pollination, whereas the male flowers of 'Otong' were prepared by drying the flowers under the sun for an hour to extract the pollen. The crosses were made from 7:00 pm onwards by brushing the pollen on the stigma of female flowers followed by wrapping it with a paper bag for 5 days. The fruits that resulted from the crosses were harvested after four months on an average.

Leaves of $32 F_{1}$ hybrids resultant from a cross breeding between Arp $8990 \times$ 'Otong' (which originated from 32 seeds of $5 \mathrm{~F}_{1}$ fruits $-71 \mathrm{~A}, 71 \mathrm{~B}, 72 \mathrm{~A}$, $72 \mathrm{~B}$, and $48 \mathrm{~B}$ ) and both parents were used as samples.

\section{Extraction of DNA}

DNA was extracted from leaves using the modified CTAB method (Doyle \& Doyle 1987). A total of $100 \mathrm{mg}$ leaves were ground with $1.5 \mathrm{ml}$ of extraction buffer ( $2 \%$ CTAB solution, $1 \% \beta$-mercaptoethanol, and $10 \mathrm{mg}$ of PVP-10). Samples were then transferred into a $2 \mathrm{ml}$ centrifuge tube and incubated at $65{ }^{\circ} \mathrm{C}$ for 60 minutes. Proteins were degraded three times with $500 \mu 1$ of chloroform isoamyl alcohol (24: 1), and then centrifuged at 12,000 rpm for 10 minutes. The DNA was precipitated with the addition of $500 \mu \mathrm{l}$ of cold isopropanol, whereas the RNA was degraded with $2 \mathrm{mg} \cdot \mathrm{ml}^{-1}$ RNAse, and then centrifuged at $12,000 \mathrm{rpm}$ for 10 minutes. The formed DNA pellets were air dried, rinsed with $70 \%$ ethanol, and dissolved in $50 \mu 1$ of TE buffer. DNA was quantified using NanoDrop equipment.

RAPD amplification, electrophoresis, and data analysis

A total of 14 primers were used in this study (Table 1). RAPD PCR reaction was performed with
Taq PCR reaction mixture $4.25 \mu 1$ (KAPPA) with $1 \mu \mathrm{l}$ of RAPD primer of concentration $1 \mu \mathrm{M}, 1 \mu \mathrm{l}$ (10 ng) of sample DNA, and $\mathrm{ddH}_{2} \mathrm{O}$ to a final volume of $12.5 \mu \mathrm{l}$ reaction. PCR was performed with the following programs: pre-denaturation at $95^{\circ} \mathrm{C}$ for 3 minutes, 45 cycles of denaturation at $95{ }^{\circ} \mathrm{C}$ for 15 seconds, annealing at $36^{\circ} \mathrm{C}$ for 15 seconds, extension at $72{ }^{\circ} \mathrm{C}$ for 5 seconds, and final extension at $72{ }^{\circ} \mathrm{C}$ for 10 minutes. The PCR formula and programs were optimized prior the actual RAPD test to ensure the reproducibility of the test as suggested by Ghazi et al. (2013). The whole experiment was run in triplicate to check for the reproducibility.

The primers were selected in order to find those which were able to show the molecular diversity of individuals. The primers' selection was conducted by using 5 samples and an array of 30 primers (prior to own unpublished research); primers that demonstrated polymorphic bands were chosen for further investigation.

DNA amplification products were separated by $1.2 \%$ agarose electrophoresis at $50 \mathrm{~V}$ for 20 minutes. The band patterns were scored manually and automatically using software BioDoc Analyzer. The Dice-Sorensen coefficient of similarity and the UPGMA method were used to construct the dendrogram. The relationship among hybrids and either parent were investigated using the Principal Co-ordinates Analysis (PCA) based on Eigen value method (Diniz-Filho et al. 1998). All the calculations were conducted using the NTSYSpc 2.10x software (Rohlf 2004), whereas the bootstrap analysis was conducted using the Win Boot software (Yap \& Nelson 1996).

\section{RESULTS AND DISCUSSIONS}

The DNA fingerprintings are considered as a helpful tool in the durian breeding program (Santoso et al. 2005; Somsri et al. 2008; Nuchuchua et al. 2008). The RAPD technique was considered to yield adequate information to assess the genetic diversity of Citrullus lanatus (Mujaju et al. 2010), Oryza sativa (Fuentes et al. 2005), Zea mays (Leal et al. 2010), and Durio spp. (Hariyati et al. 2013).

Out of the 30 tested primers, 14 primers produced polymorphic bands of good quality. They 
amplified a total of 114 scoring bands, $112(98.2 \%)$ of them were polymorphic, with 4 to 11 bands per primer (Table 1, Fig. 1). The band patterns differing from parents, can suggest the traits combination occurring from the crossings.

The polymorphic level in this study was higher as compared to Ruwaida et al. (2009) that used 6 RAPD primers to assess the genetic diversity of D. zibethinus (74 polymorphic out of 90 bands, $82.2 \%$ ), Vanijajiva (2011) (9 primers generating 34 polymorphic out of 90 bands, $37.7 \%$ ), and Hariyati et al. (2013) (5 primers produced 61 polymorphic out of 81 bands, $75.3 \%$ ) The chosen RAPD markers in our study revealed more polymorphic loci than the previous study.

The analysis of electrophoretic separation showed that all hybrids had at least one band similar with one of the parents; some hybrids produced additional bands compared to both parents; others showed similar or less bands than parents, as also reported by Saran et al. (2015) who analyzed the hybrids from papaya crossbreeding. Furthermore, the RAPD method was suitable to identify progenies deriving from hybridization of Citrus (Elisiário et al. 1999; Qin et al. 2011), as well as on Salix (Triest et al. 2000), Populus deltoides (Rajora \& Rahman 2003), Mentha (Shasany et al. 2005), Vanilla (Divakaran et al. 2006), and Saccharum officinarum (Zhang et al. 2008). It was also suggested that the RAPD data analysis might be used in the construction of molecular linkage map (Luo et. al. 2002; Lin et al. 2005).

The similarity of coefficients obtained from the data ranged from $0.141[71 \mathrm{~B}(4)$ and $72 \mathrm{~B}(15)]$ to $0.776[71 \mathrm{~B}(15)$ and $48 \mathrm{~B}(1)]$. A phylogenetic tree showing genetic relationships for 34 accessions of durian hybrid crosses is shown in Fig. 2. The cophenetic correlation between the genetic similarity matrix and the cluster analysis was 0.87 , suggesting a high goodness of fit. In order to confirm the genetic structure or degree differentiation among clusters, the PCA was performed. It indicated that the first two principal components accounted for $34 \%$ of the total variation, while the third component accounted for an additional $6 \%$. The contributions of the remaining components individually were less than $5 \%$ each.

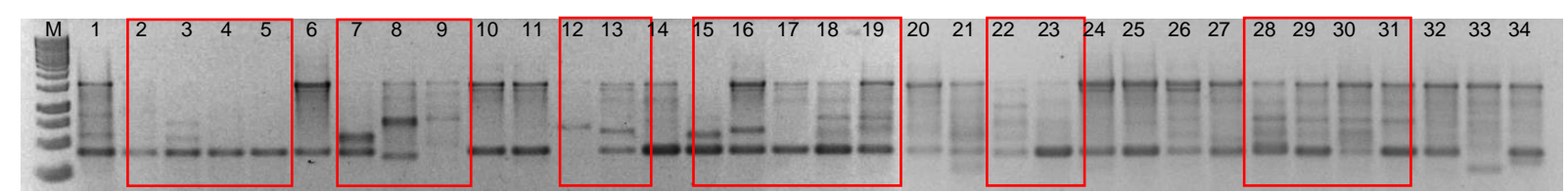

a

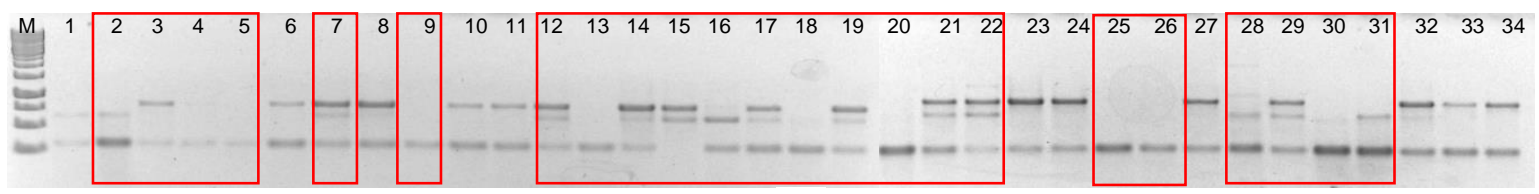

b

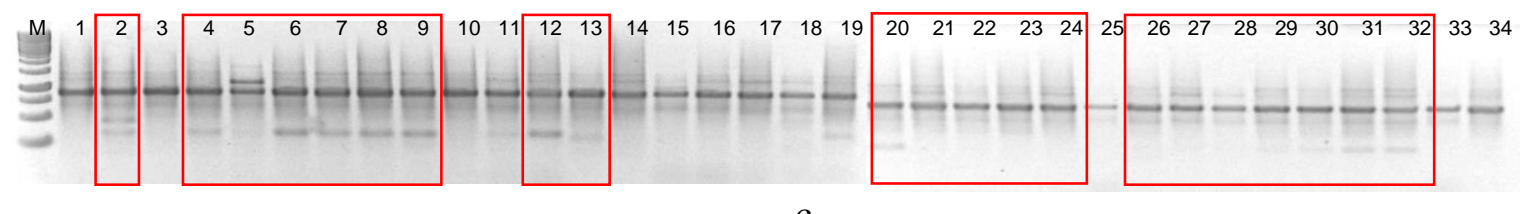

c

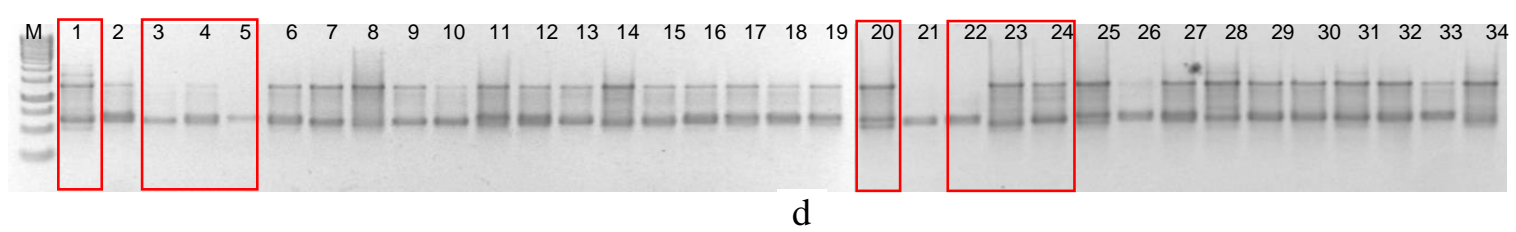

Fig. 1. The electrophoresis gel of PCR using primers (a) RAPD2, (b) RAPD3, (c) RAPD4, and (d) OPA02 (M 1kb marker; 1-32 hybrids, 33: male parents 'Otong', and 34 female parents Arp 8990; red boxes contain hybrids that produced different patterns than parents. 
Table 1. Selected RAPD primers, total of amplified bands, number of polymorphic bands, and polymorphic percentage

\begin{tabular}{l|lcrc}
\hline Primers & Sequence (5'-3') & $\begin{array}{c}\text { Total of ampli- } \\
\text { fied band }\end{array}$ & $\begin{array}{c}\text { Polymorphic } \\
\text { band }\end{array}$ & $\begin{array}{c}\text { Polymorphic } \\
\text { percentage }(\%)\end{array}$ \\
\hline RAPD1 & GCGGGTGGAA & 11 & 11 & 100 \\
RAPD2 & GTT TCGCTCC & 8 & 8 & 100 \\
RAPD3 & GTAGACCC T & 6 & 6 & 100 \\
RAPD4 & AAGAGCCCGT & 10 & 9 & 90 \\
RAPD5 & AACGCGCAAC & 14 & 14 & 100 \\
RAPD6 & CCCGTCAGCA & 8 & 8 & 100 \\
OPA01 & CAGGCCCTTC & 5 & 5 & 100 \\
OPA02 & TGCCGAGCTG & 6 & 5 & 83.3 \\
OPA03 & AGTCAGCCAC & 5 & 5 & 100 \\
OPA07 & GAAACGGGTG & 4 & 4 & 100 \\
OPA10 & GTGATCGCAG & 7 & 7 & 100 \\
OPA13 & CAGCACCCAC & 11 & 11 & 100 \\
OPA18 & AGGTGACCGT & 11 & 11 & 100 \\
OPA19 & CAAACGTCGG & 8 & 8 & 100 \\
\hline
\end{tabular}

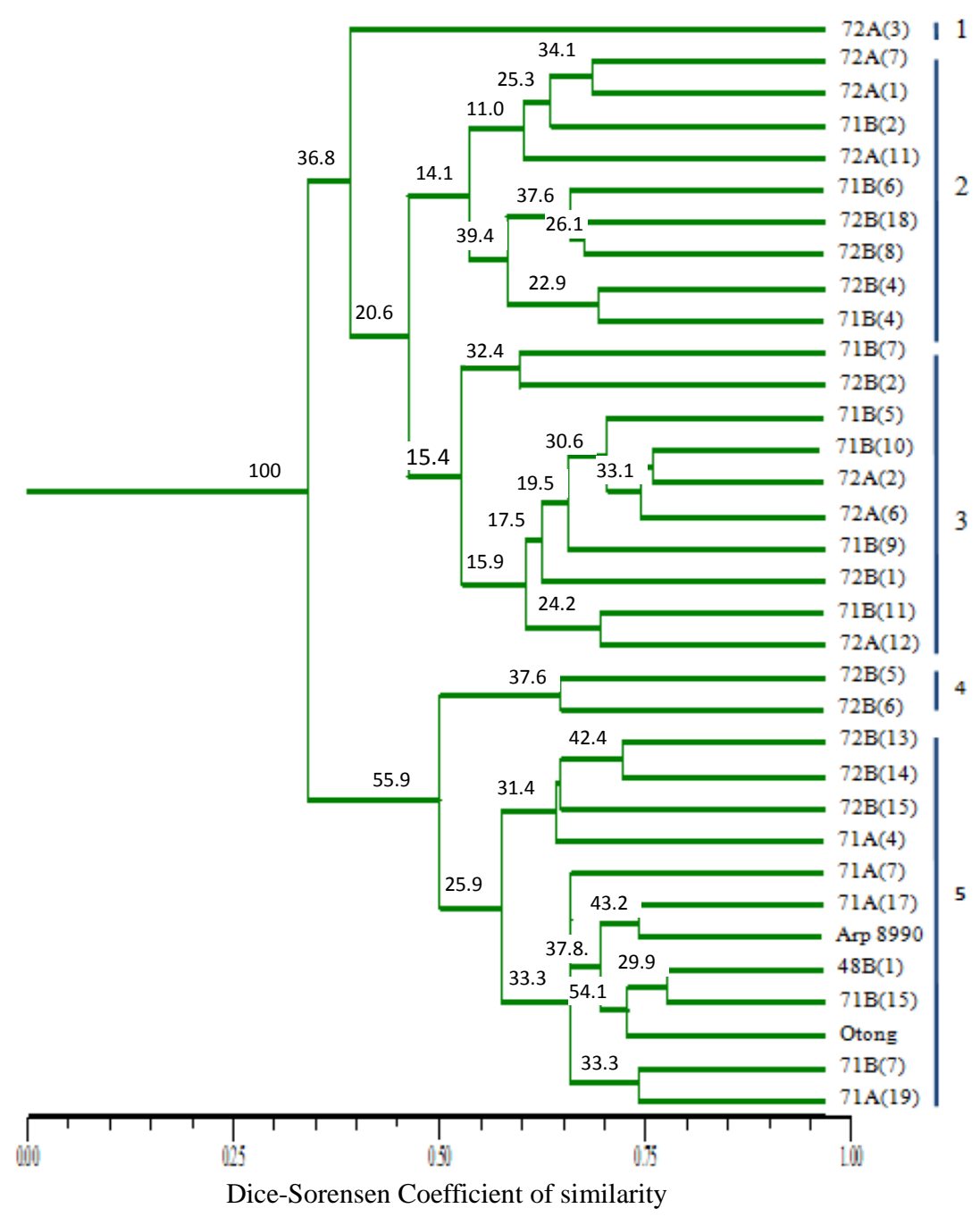

Fig. 2. The phylogenetic relationship among the 32 durian $F_{1}$ hybrids and both their parents (Arp 8990 and 'Otong') based on 114 bands resulting from PCR-RAPD using Dice-Sorensen coefficient of similarity and UPGMA method. Numbers on the branch show the bootstrap value 


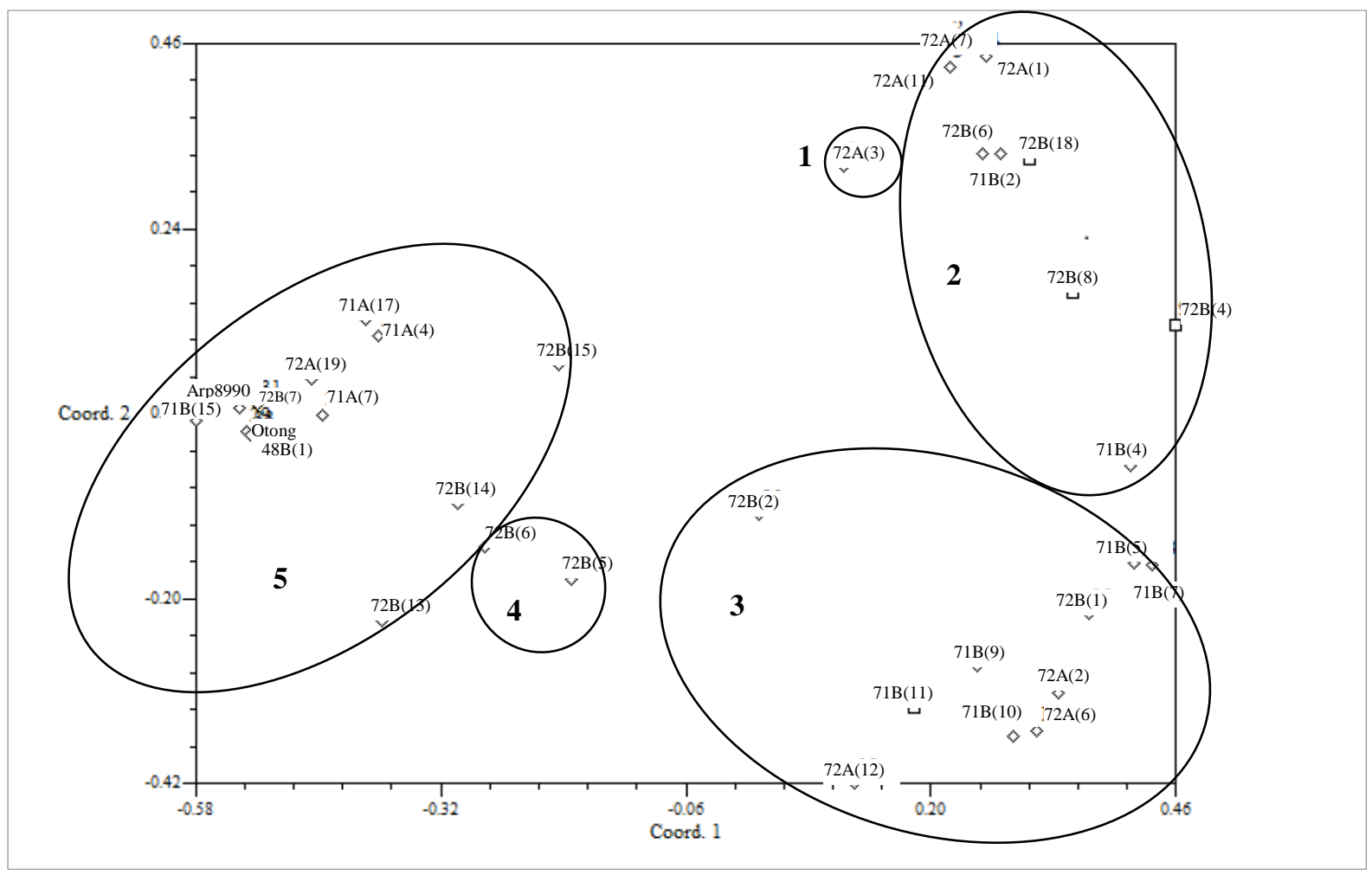

Fig. 3. PCA of 32 durian crosses hybrid together with both their parents (Arp 8990 and 'Otong') based on the Eigen vector method

Therefore, the biplot of only the first two principal components is presented in Fig. 3. The comparable dendrogram (Fig. 2) and PCA results (Fig. 3) indicate that both analyses give similar results.

The samples were grouped in five clusters (Fig. 2). The data showed that the coefficient similarity between Arp 8990 and 'Otong' was 0.742 and they were grouped in the same cluster (cluster 5). The Arp 8990 is a local variety grown in sub-district of Solok, West Sumatra. Although there is no published productivity data for the Arp 8990, this female parent produces a high number of fruits per cluster (6 fruits/cluster), however it has a small edible portion and a non-preferred taste. On the other hand, the 'Otong' is a commercial cultivar originating from Thailand with moderate number of fruit per cluster ( 3 fruits per cluster), a high edible portion, and preferred taste. The two parents were crossed in order to obtain hybrids of a high productivity (high number of fruit per cluster), high edible portion, and preferred taste.
The $F_{1}$ hybrids resultant from the Arp $8990 \times$ 'Otong' had a distinct genetic distance from both parents. The smallest coefficient of similarity among the hybrids and parents were 0.149 ['Otong' and $72 \mathrm{~B}(4)$ ]; the largest coefficient similarity was 0.762 ['Otong' and 48B(1)]. These data suggested that the hybrids should have different morphological characteristics thasn both parents, which is an important factor for the rapid genetic improvement in crops (Trethowan \& Mujeeb-Kazi 2008).

Among the samples, the $72 \mathrm{~A}(3)$, a single hybrid was placed in cluster 1 , whereas other hybrids of $72 \mathrm{~A}$ were scattered in other 2 clusters (cluster 2 and 3), but none in the same cluster with both parents. The similar phenomenon occurred on hybrids of 71B, which were scattered into 3 clusters, including the cluster with both parents. This data illustrated that the seeds from the same fruit (coded by 71, 72, and 48) might possess different molecular characteristics. This data correlated with Hariyati et al. (2013), who suggested that by using 5 RAPD primers on 16 hybrids, the analysis was capable of 
showing genetic diversity of hybrids produced from durian crosses clustered either with the same group with one of the parent or between the hybrids themselves. Thus, the data retrieved from the larger number of polymorphic RAPD markers in the present study strengthened the previous results.

The durian hybrids used in this study were obtained in 2010. By this date, they are 5 years old, and still are at the vegetative stage. Although previous genetic studies did not reveal reliability for predicting $\mathrm{F}_{1}$ yield and heterosis on Triticum aestivum (Liu et al. 1999) or Brassica napus (Yu et al. 2005), the molecular analysis in the present study showed a promising selection material for the Indonesian and Thailand (Somsri et al. 2014) durian breeding programs.

\section{CONCLUSION}

The crossing of durian plants produced $F_{1}$ hybrids of a distant genomic composition from both parents. These hybrids might be used as materials in breeding program.

\section{Acknowledgment}

We would like to acknowledge Ms. Dwi Wahyuni Ardiana for the assistance in this study.

\section{REFERENCES}

Bardakci F. 2001. Random amplified polymorphic DNA (RAPD) markers. Turkish Journal of Biology 25: 185-196.

Brown M.J. 1997. Durio - A bibliographic review. (R.K. Arora, V. Ramanatha Rao, A.N. Rao, eds) IPGRI office for South Asia, New Delhi, India, 188 p.

Diniz-Filho J.A.F, de Sant'Ana C.E.R., Bini L.M. 1998. An eigenvector method for estimating phylogenetic inertia. Evolution 52(5): 1247-1262. DOI: 10.2307/2411294.

Divakaran M., Babu K.N., Ravindran P.N., Peter K.V. 2006. Interspecific hybrization in vanilla and molecular characterization of hybrids and selfed progenies using RAPD and AFLP markers. Scientia Horticulturae 108(4): 414-422. DOI: 10.1016/j.scienta.2006.02.018.

Doyle J.J., Doyle J.L. 1987. A rapid DNA isolation procedure for small quantities of fresh leaf tissue. Phytochemical Bulletin 19: 11-15.
Fuentes J.L., Cornide M.T., Alvarez A., Suarez E., Borges E. 2005. Genetic diversity analysis of rice varieties (Oryza sativa L.) based on morphological, pedigree and DNA polymorphism data. Plant Genetic Resources 3(3): 353-359. DOI: 10.1079/PGR200588.

Elisiário P.J, Justo E.M., Leitão J.M. 1999. Identification of mandarin hybrids by isozyme and RAPD analysis. Scientia Horticulturae 81(3): 287-299. DOI: 10.1016/S0304-4238(99)00013-8.

Gerrano A.S., Labuschagne M.T., van Biljon A., Shargie N.G. 2014. Genetic diversity assessment in sorghum accessions using qualitative morphological and amplified fragment length polymorphism markers. Scientia Agricola 71(5): 394-401. DOI: 10.1590/0103-9016-2013-0251.

Ghazi F., Benmechernene Z., Kihal M., Gurakan G.C. 2013. The reproducibility of random amplified polymorphic DNA (RAPD) profiles of Streptococcus thermophilus strains with XD9, M13, and OPI-02 MOD primers. African Journal of Biotechnology 12(44): 6245-6252. DOI: 10.5897/AJB2013.12870.

Gratani L. 2014. Plant phenotypic plasticity in response to environmental factors. Advances in Botany, Article ID 208747, 17 p. DOI: 10.1155/2014/208747.

Hariyati T., Kusnadi J., Arumingtyas E.L. 2013. Genetic diversity of hybrid durian resulted from cross breeding between Durio kutejensis and Durio zibethinus based on random amplified polymorphic DNAs (RAPDs). American Journal of Molecular Biology 3(3): 153-157. DOI: 10.4236/ajmb.2013.33020.

Janyszek M., Jagodziński A.M., Janyszek S., WrońskaPilarek D. 2008. Morphological variability of Carex spicata Huds. utricles among plant communities. Flora - Morphology, Distribution, Functional Ecology of Plants 203(5): 386-395. DOI: 10.1016/j.flora.2007.06.007.

Klingenberg C.P., Duttke S., Whelan S., Kim M. 2011. Developmental plasticity, morphological variation and evolvability: a multilevel analysis of morphometric integration in the shape of compound leaves. Journal of Evolutionary Biology 25(1): 115-129. DOI: $10.1111 /$ j.1420-9101.2011.02410.x

Leal A.A., Mangolin C.A., do Amaral Júnior A.T., Gonçalves L.S.A., Scapim C.A., Mott A.S. et al. 2010. Efficiency of RAPD versus SSR markers for determining genetic diversity among popcorn lines. Genetics and Molecular Research 9(1): 9-18. DOI: 10.4238/vol9-1gmr692.

Liu Z.Q., Pei Y., Pu Z.J. 1999. Relationship between hybrid performance and genetic diversity based on 
RAPD markers in wheat, Triticum aestivum L. Plant Breeding 118(2): 119-123. DOI: 10.1046/j.1439-0523.1999.118002119.x.

Lin Z., He D., Zhang X., Nie Y., Guo X., Feng C., Stewart J.McM. 2005. Linkage map construction and mapping QTL for cotton fibre quality using SRAP, SSR and RAPD. Plant Breeding 124(2): 180-187. DOI: 10.1111/j.1439-0523.2004.01039.x.

Luo S., He P., Zheng X., Zhou P. 2002. Inheritance of RAPD markers in an interspecific $F_{1}$ hybrid of grape between Vitis quinquangularis and $V$. vinifera. Scientia Horticulturae 93(1): 19-28. DOI: 10.1016/S0304-4238(01)00309-0.

Mujaju C., Sehic J., Werlemark G., Garkava-Gustavsson L., Fatih M., Nybom H. 2010. Genetic diversity in watermelon (Citrullus lanatus) landraces from Zimbabwe revealed by RAPD and SSR markers. Hereditas 147(4): 142-153. DOI: 10.1111/j.16015223.2010.02165.x.

Nanthachai S. 1994. Durian: fruit development, postharvest physiology, handling and marketing in ASEAN. ASEAN Food Handling Bureau, Kuala Lumpur, Malaysia, $156 \mathrm{p}$.

Nuchuchua O., Chaipornpokin W., Maktrirat R., Phummiratch D., Pongsamart S., Sukrong S. 2008. Characterization of Durio zibethinus by molecular marker and soluble polysaccharide in fruit rinds. Acta Horticulturae 786: 107-113. DOI: 10.17660/ActaHortic.2008.786.11.

Qin Y.H., Hu H.G., Ye Z.X., Lin S.Q., Miao H.X., Zhang C.Y., Hu G.B. 2011. Identification of progenies derived from sexual hybridization of citrus using RAPD molecular marker. Acta Horticulturae 894: 123-132. DOI: 10.17660/ActaHortic.2011.894.12.

Rajora O.P., Rahman M.H. 2003. Microsatellite DNA and RAPD fingerprinting, identification and genetic relationships of hybrid poplar (Populus $\times$ canadensis) cultivars. Theoretical and Applied Genetics 106(3): 470-477. DOI: 10.1007/s00122002-1082-2.

Rivero-Guerra A.O. 2011. Morphological variation within and between taxa of the Santolina rosmarinifolia L. (Asteraceae: Anthemideae) aggregate. Systematic Botany 36(1):171-190. DOI: $10.1600 / 036364411 X 553261$.

Rohlf F.J. 2004. NTSYSpc: Numerical taxonomy and multivariate analysis system, version 2.1. Exeter Software, New York, 38 p.

Ruwaida I.P., Supriyadi, Parjanto 2009. Variability analysis of Sukun durian plant (Durio zibethinus) based on RAPD marker. Nusantara Bioscience 1(2): 84-91.
Saran P.L., Choudhary R., Solanki I.S., Patil P., Kumar S. 2015. Genetic variability and relationship studies in new Indian papaya (Carica papaya L.) germplasm using morphological and molecular markers. Turkish Journal of Agriculture and Forestry 39(2): 310-321. DOI: 10.3906/tar-1409-148

Santoso P.J., Saleh G.B., Saleh N.M., Napis S. 2005. Phylogenetic relationships amongst 10 Durio species based on PCR-RFLP analysis of two chloroplast genes. Indonesian Journal of Agricultural Science 6(1): 20-27. DOI: 10.21082/ijas.v6n1.2005.20-27.

Shasany A.K., Darokar M.P., Dhawan S., Gupta A.K., Gupta S., Shukla A.K. et al. 2005. Use of RAPD and AFLP markers to identify inter- and intraspecific hybrids of Mentha. Journal of Heredity 96(5): 542-549. DOI: 10.1093/jhered/esi091.

Somsri S., Vichitrananda S., Kengkat P., Koonjanthuk P., Chunchim S., Sesuma S., Jintanawongse S., Salakphet S. 2008. Three decades of durian breeding program in Thailand and its three newly recommended $F_{1}$ hybrids. Acta Horticulturae 787: 77-87. DOI: 10.17660/ActaHortic.2008.787.6.

Somsri S. 2014. Current status of durian breeding program in Thailand. Acta Horticulturae 1024: 51-59. DOI: 10.17660/ActaHortic.2014.1024.3.

Triest L., de Greef B., de Bondt R., van Slycken J. 2000. RAPD of controlled crosses and clones from the field suggests that hybrids are rare in the Salix alba-Salix fragilis complex. Heredity 84(5): 555563. DOI: 10.1046/j.1365-2540.2000.00712.x.

Trethowan R.M., Mujeeb-Kazi A. 2008. Novel germplasm resources for improving environmental stress tolerance of hexaploid wheat. Crop Science 48(4): $1255-1265$. DOI: $10.2135 /$ cropsci2007.08.0477.

Vanijajiva O. 2011. Genetic variability among durian (Durio zibethinus Murr.) cultivars in the Nonthaburi province, Thailand detected by RAPD analysis. Journal of Agricultural Technology 7(4): 1105-1114.

Welsh J., McClelland M. 1990. Fingerprinting genomes using PCR with arbitrary primers. Nucleic Acids Research 18(24): 7213-7218.

Williams J.G.K., Kubelik A.R., Livak K.J., Rafalski J.A., Tingey S.V. 1990. DNA polymorphisms amplified by arbitrary primers are useful as genetic markers. Nucleic Acids Research 18(22): 6531-6535. DOI: 10.1093/nar/18.22.6531.

Withlock R., Grime J.P., Burke T. 2010. Genetic variation in plant morphology contributes to the specieslevel structure of grassland communities. Ecology 91(5):1344-1354. 
Yap I.V., Nelson R.J. 1996. WinBoot: A program for performing bootstrap analysis of binary data to determine the confidence limits of UPGMA-based dendrograms. IRRI Discussion Paper Series 14. IRRI, Manila, $32 \mathrm{p}$.

Yu C.Y., Hu S.W., Zhao H.X., Guo A.G., Sun G.L. 2005. Genetic distances revealed by morphological characters, isozymes, proteins and RAPD markers and their relationships with hybrid performance in oilseed rape (Brassica napus L.). Theoretical and Applied Genetics 110(3): 511-518. DOI: 10.1007/s00122-004-1858-7.

Zhang H.Y., Li F.S., He I.L., Zhong H.Q., Yang Q.H., He S.C. 2008. Identification of sugarcane interspecies hybrids with RAPDs. African Journal of Biotechnology 7(8): 1072-1074. 